\title{
Integration of Energy-Efficient Ventilation Systems in Historic Buildings-Review and Proposal of a Systematic Intervention Approach
}

\author{
Alexander Rieser ${ }^{1, *}$, Rainer Pfluger ${ }^{1}$, Alexandra Troi ${ }^{2}$, Daniel Herrera-Avellanosa ${ }^{2}$, \\ Kirsten Engelund Thomsen ${ }^{3}\left(\mathbb{D}\right.$, Jørgen Rose ${ }^{3}(\mathbb{D})$, Zeynep Durmuş Arsan ${ }^{4} \mathbb{D}_{\text {, Gulden Gokcen Akkurt }}^{4}$, \\ Gerhard Kopeinig ${ }^{5}$, Gaëlle Guyot ${ }^{6,7}$ and Daniel Chung ${ }^{8}$ \\ 1 University of Innsbruck, 6020 Innsbruck, Austria; rainer.pfluger@uibk.ac.at \\ 2 Eurac Research, 39100 Bozen, Italy; alexandra.troi@eurac.edu (A.T.); daniel.herrera@eurac.edu (D.H.-A.) \\ 3 Department of the Built Environment, Aalborg University, 2450 Copenhagen SV, Denmark; \\ ket@build.aau.dk (K.E.T.); jro@build.aau.dk (J.R.) \\ 4 Izmir Institute of Technology, 35430 İzmir, Turkey; zeynepdurmus@iyte.edu.tr (Z.D.A.); \\ guldengokcen@iyte.edu.tr (G.G.A.) \\ 5 ARCH+MORE ZT GmbH, 9220 Velden am Wörthersee, Austria; arch@archmore.cc \\ 6 Cerema, BPE Project Team, 46, rue St Théobald, F-38080 L'Isle d'Abeau, France; gaelle.guyot@cerema.fr \\ 7 University of Savoie Mont Blanc, CNRS, LOCIE, 73000 Chambéry, France \\ 8 Drexel University, Philadelphia, PA 19104, USA; dhc38@drexel.edu \\ * Correspondence: alexander.rieser@uibk.ac.at; Tel.: +43-512-507-63621
}

check for updates

Citation: Rieser, A.; Pfluger, R.; Troi, A.; Herrera-Avellanosa, D.; Thomsen, K.E.; Rose, J.; Arsan, Z.D.; Akkurt, G.G.; Kopeinig, G.; Guyot, G.; et al. Integration of Energy-Efficient Ventilation Systems in Historic Buildings-Review and Proposal of a Systematic Intervention Approach. Sustainability 2021, 13, 2325. https:// doi.org/10.3390/su13042325

Academic Editor: Vincenzo Costanzo

Received: 22 December 2020

Accepted: 10 February 2021

Published: 20 February 2021

Publisher's Note: MDPI stays neutral with regard to jurisdictional claims in published maps and institutional affiliations.

Copyright: (c) 2021 by the authors Licensee MDPI, Basel, Switzerland. This article is an open access article distributed under the terms and conditions of the Creative Commons Attribution (CC BY) license (https:/ / creativecommons.org/licenses/by/ $4.0 /)$.

\begin{abstract}
Historic building restoration and renovation requires sensitivity to the cultural heritage, historic value, and sustainability (i.e., building physics, energy efficiency, and comfort) goals of the project. Energy-efficient ventilation such as demand-controlled ventilation and heat recovery ventilation can contribute to the aforementioned goals, if ventilation concepts and airflow distribution are planned and realized in a minimally invasive way. Compared to new buildings, the building physics of historic buildings are more complicated in terms of hygrothermal performance. In particular, if internal insulation is applied, dehumidification is needed for robust and risk-free future use, while maintaining the building's cultural value. As each ventilation system has to be chosen and adapted individually to the specific building, the selection of the appropriate system type is not an easy task. For this reason, there is a need for a scientifically valid, systematic approach to pair appropriate ventilation system and airflow distribution solutions with historical buildings. This paper provides an overview of the interrelationships between heritage conservation and the need for ventilation in energy-efficient buildings, regarding building physics and indoor environmental quality. Furthermore, a systematic approach based on assessment criteria in terms of heritage significance of the building, building physics (hygrothermal performance), and building services (energy efficiency, indoor air quality, and comfort rating) according to the standard EN 16883:2017 are applied.
\end{abstract}

Keywords: building services; ventilation; historic buildings; refurbishment; indoor air quality; assessment criteria

\section{An Introduction in Ventilation in Historical Buildings}

Fresh air is a fundamental human need and also contributes to a significant increase in indoor environmental comfort. The removal of odors and harmful pollutants has an immediately noticeable effect, and the removal of excessive humidity is necessary for the preservation and protection of the building fabric.

Natural ventilation via window openings and infiltration through air leakage was the traditional and primary means of indoor/outdoor air exchange in historic buildings [1,2]. For that reason, the natural air exchange rate has been the primary method in historic 
buildings attributed to long-term conservation of building materials and components, thermal comfort of occupants, and increased indoor air quality. During the heating period in cold climates, the natural air exchange rate is driven (in addition to wind and temperature difference) by the negative pressure airflows created by open-flue single ovens (due to the stack effect) [3,4]. Historic libraries, museums, palaces, and sanctuaries were deliberately constructed with passive ventilation control mechanisms in order to satisfy preventive conservation requirements of their cultural artifacts and collections $[5,6]$.

The challenges of reducing energy consumption in the building sector have clearly influenced the evolution of air permeability and ventilation strategies in buildings [7-11]. From an energy point of view, natural ventilation performance clearly depends on the different seasons and climates. In regions with Mediterranean climate or during warm summer months, natural ventilation can contribute to energy efficiency of buildings with high thermal inertia via night-time cooling [12-14]. However, even if the passive (freefloating) hygrothermal behavior contributes to maintain adequate indoor air quality in buildings, and also because in colder climates natural ventilation alone is not efficient enough $[15,16]$, the need for increasing the energy efficiency of the existing building stock will inevitably lead to more airtight historic buildings and introduction of energy-efficient mechanical systems, including demand-controlled [17-22] and heat recovery ventilation (HRV) systems [23,24].

In addition to the technical and energy efficiency aspects, the architectural and especially the historic heritage aspects have to be considered when refurbishing historic buildings. On the one hand, ventilation is essential for the preservation of historic building fabric. On the other hand, the building's cultural heritage should be preserved and not visually impaired. Traditional mechanical ventilation systems with innumerable piping, supply, and exhaust air openings are usually frowned upon and cannot be easily integrated in historic buildings.

To close this gap, the Solar Heating and Cooling Programme-International Energy Agency (IEA SHC) Task 59 [25] and ATLAS Interreg Alpine Space project [26] intend to adapt existing approaches for the refurbishment of historic buildings. First, a review of the interrelated effects on air quality and building physics related to ventilation in historic buildings is given. Second, based on this review, a systematic approach (adapted from the assessment system of EN-16883:2017 [27]) is presented to demonstrate how different ventilation solutions that focus on the preservation of historical buildings and energy efficiency can be achieved.

\section{Interrelated Effects in Connection with Ventilation Systems in Historical Buildings-A Review}

In this section, we propose a review of literature demonstrating the important relationships between ventilation (whatever the strategy-natural or mechanical) and other building parameters. Our next goal is to identify a general intervention approach in order to implement energy-efficient ventilation strategies which are compatible with historic buildings, also considering building conservation, building architecture, and Indoor Environmental Quality (IEQ). This methodology should take into account the crucial parameters identified in this review.

\subsection{Building Envelope Physics Due to Internal Insulation: Ventilation Strategy, Internal Temperatures, and Hygrothermal Risk}

Internal insulation is nearly always the energy retrofitting solution for historic buildings, due to architectural protection. It leads to specific issues in relation to ventilation strategies, internal temperatures, and hygrothermal risk.

Exner et al. [28] have shown through the example of the historic Waaghaus in Bozen, Italy, that it is important to consider the correlation between energy retrofit measures, ventilation strategy, and the impact on hygrothermal risk. In this heritage building, as both interior and exterior surfaces were original plaster, for conservation reasons, no wall insulation was foreseen-with relative temperature factor on the internal surface [29] (p. 33) 
$\left(f_{\text {Rsi }}=0.477\right)$ and bays $\left(f_{R s i}=0.356\right)$, and potential risk of mold growth. Local regulation would have asked for a minimum value of $\mathrm{f}_{\text {Rsi,crit }}=0.587$, considering $20{ }^{\circ} \mathrm{C}$ and $50 \%$ and no ventilation system (thus saying that the hygrothermal risk is expected to be too high). The authors performed a dynamic simulation of the air exchange and resulting humidity levels using CONTAM $[30,31]$. They showed for the expected use that opening windows just during lunch break periods results in a relative humidity exceeding $60 \%$ and $\mathrm{f}_{\text {Rsi,crit }}=0.614$. As a result, to avoid mold growth, inner surface temperature has to be even higher than asked by regulation. A better natural ventilation strategy with open windows three times a day (morning $15 \mathrm{~min}$ windows open, windows tilted 45 min during lunch break, late afternoon $15 \mathrm{~min}$ windows open) to avoid high moisture loads remaining there overnight) keeps the relative humidity in the rooms mostly well below $50 \%$ and allows

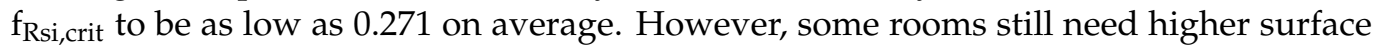
temperatures. With an active overflow ventilation system (described in Section 4.1.2), $\mathrm{f}_{\text {Rsi,crit }}=0.199$ is achievable even in the most unfavorable rooms. Thus, surface temperature is not an issue anymore, due to the relative humidity being low enough. This example demonstrates the significant influence ventilation behavior has on building functionality. Whether the renovation works in its entirety or not, in this case, depends primarily on the relative humidity of the indoor air.

Depending on the region and season, the outdoor conditions (in terms of temperature and relative humidity, but also radiation and driving rain) vary considerably. Outdoor climate cannot be changed in the course of a refurbishment, but it is definitely possible to influence the indoor climate. Un-refurbished historic buildings, outside of modern expectations of living comfort and energy efficiency, have been functioning for hundreds of years. For this reason, it is important to be aware of the effects of various interventions. If airtightness is increased, the temperature of the inner surface needs to be raised by improving the thermal properties of the envelope.

Especially with historic buildings, the refurbishment of the thermal properties of the envelope is a challenge. In most cases, the appearance of the historic facade is a cultural characteristic of the building style and the era in which it was originally built. For this reason, external insulation is typically not an option and internal insulation is the preferred treatment. However, internal insulation drastically reduces the temperatures inside of the original wall as a result of the different thermal resistance ratios and material properties between existing and retrofit materials. If the warm humid air meets the colder inner surface of the original wall due to diffusion or convection, mold growth can rapidly exceed acceptable limits [32]. In the case of historic log walls or half-timber houses, the wood structure may rot. This can be avoided to a large extent by selecting the right materials and systems, a residual risk remains due to manufacturing defects, which can be reduced considerably by an appropriate ventilation system. Through the controlled removal of excess indoor air humidity, vapor diffusion can be mitigated by reducing the gradient and making the internal insulation system much more resistant against mold growth. Simulations on a historic log wall with a capillary-active cellulose insulation interior retrofit showed that the difference between a successful and unsuccessful wall retrofit strongly depends on the boundary condition of the interior air [33].

Besides the wall itself, critical details, such as wooden beam connections within ceilings, used in combination with internal insulation, can experience damage under high indoor air humidity, but work well at low indoor air humidity. Within the EU project 3encult, three years of monitoring data of relative humidity and temperature inside the living room and at the critical point of the wooden beam end were analyzed and compared with hygrothermal simulation [34] (pp. 289-292/295-296). Without a ventilation system, the wood beam end takes 3 years of drying time, whereas with mechanical ventilation and constantly low indoor air humidity, the humidity level within the construction is uncritical from the first year on. The aforementioned example does not reduce the inherent need for driving rain protection and appropriate hygrothermal materials but is meant to stress that dry indoor air conditions will reduce moisture-related damage risk significantly. 


\subsection{Ventilation, Occupants, and Indoor Environmental Quality in Historic Buildings}

The pollutant sources combined with airflows, due to air permeability of the envelope, ventilation systems, and users' operation of windows and openings, determine the IEQ of buildings. Research on current or recommended exchange rates in historic buildings is still very limited and often contradictory [35-38], as in all types of buildings in general [39-41]. Despite scientific evidence [42], and because the integration of mechanical ventilation systems is seen in many cases as a concerning issue due to the compatibility with traditional structures [43], it is often found in the literature (mostly publications aimed at practitioners and owners) that historic buildings should rely mostly on natural ventilation [44]. However, approaches relying exclusively on natural ventilation must be framed with the assumption that users ventilate their home as people did in the past [45].

Empirical research has found that in some cases, the IEQ in non-retrofitted historic buildings is far from ideal, with very high levels of relative humidity and considerable low temperatures, mostly due to the fact that they are very expensive to heat and people minimize air exchange as a way to reduce their energy bill [46]. In a study on a historical center in Northern Portugal, authors highlighted the water-related problems as the single most important defect at the building stock scale [47]. They highlight that the poor quality of envelopes and the lack of ventilation has a strong influence on condensation phenomena. Also, in renovated cases, the lack of mechanical systems that actuate automatically to restore adequate IEQ has resulted in high levels of relative humidity [48]. Kalamees et al. [49] investigated indoor environmental quality in four manor schools in the Estonian cold climate. They measured higher $\mathrm{CO}_{2}$ and airborne mold concentrations, combined with higher humidity loads for the building envelope, in classrooms equipped with natural ventilation (original passive stack effect and from window-airing) [47,49-51]. Airflow rate ranged from 1.1 to $1.5 \mathrm{~L} / \mathrm{s} /$ person (or $0.8-0.9 \mathrm{~L} / \mathrm{s} / \mathrm{m}^{2}$ ), far from the 6 to $8 \mathrm{~L} / \mathrm{s} /$ person (or $3 \mathrm{~L} / \mathrm{s} / \mathrm{m}^{2}$ ) recommended. Regarding thermal comfort, Martinez-Molina et al. [52] have already presented a comprehensive review of the relation between renovation of historic buildings and air quality.

Building occupant behavior and building use are critical factors in IEQ. Independent of whether a building is historic, retrofitted, or new, "people react to the changes in the environment that cause discomfort in order to restore their comfort" [53] (p. 358). Occupant action to ameliorate thermal discomfort is a significant factor contributing to low IEQ found in some households. When users were not able to reach a thermally comfortable environment quickly, they changed the building heating and ventilation use patterns, resulting in new and repeated practices with negative effects on the IEQ (such as high humidity, low air exchange rates, or low surface temperatures) [46]. Notably, in the cases where the causes of discomfort were recurrent, occupants ignored the negative impact that their behavior had on the IEQ, despite knowing and understanding it. This is probably also due to the fact that humans do not have an accurate perception of air humidity [54]. According to some authors, opening of windows is primarily due to occupant personality, without any correlation to the ventilation system, or to the level of pollution observed [55]. Even in the case of Mediterranean historic cities with mild winters, increased levels of pollutants and $\mathrm{CO}_{2}$ are found in bedrooms as a consequence of user interaction with the building [56].

Research has shown that natural ventilation is a balancing act between positive (removing pollutants and odors, reducing relative humidity) and negative (increased noise levels, lower air and surface temperatures, higher energy demand) aspects of air exchange. As a conclusion, natural ventilation has clearly demonstrated to be inadequate to provide a good IEQ when it is entirely user-driven and thus, ventilation systems will play a crucial role in achieving high-performing historic buildings, while at the same time ensuring adequate IEQ, whether by means of traditional natural solutions linked to chimneys and cupolas [57] or modern mechanical systems [58]. 


\subsection{Ventilation and Airtightness in Historic Buildings}

Today, airtightness is an important factor in the overall quality of a building. On the one hand, large leakage rates guarantee an exchange of air and increased airtightness is sometimes also presented as a concern because of the potential undesirable impact on moisture accumulation and indoor air quality [36,59]. On the other hand, uncontrolled leaks in the building envelope lead to high energy losses and influence both the energy used for heating and/or cooling and the internal air quality in residential and non-residential buildings [60].

Therefore, air changes should, when possible, be supplied by mechanical ventilation and the ventilation system should be energy-efficient, either equipped with heat recovery or using demand-controlled airflows. Another issue that can be related to a lack of airtightness is moisture accumulation in building envelope constructions. If warm, humid air enters the envelope construction through cracks and gaps caused by convection, the resulting moisture transport is about two orders of magnitude higher than the transport due to pure diffusion. Depending on the system, serious damage can occur [61].

Eskola et al. [42] investigated airtightness, air exchange rates, and energy performance in 68 historic naturally ventilated houses in Sweden, Finland, and Estonia. They conclude that tightening the envelope and moving from natural to mechanical ventilation with heat recovery were the most effective means for improving the indoor conditions and energy performance of the studied historic houses. In the same case study, Alev [62] analyzed the air exchange rates of historic buildings with log-walls by air tightness measurements with a blower-door test according EN 13829 [63]. The average value for the air leakage rate (generated pressure difference of 50 Pascal) was $n_{50}=21 \mathrm{~h}^{-1}$ (values ranged between 5.1 and $56 \mathrm{~h}^{-1}$ ). If these high air leakage rates are compared with the recommended air leakage rates for the installation of a mechanical ventilation system $\left(\mathrm{n}_{50}<1.50 \mathrm{~h}^{-1}\right)$ or for new buildings on passive house standard $\left(\mathrm{n}_{50}<0.6 \mathrm{~h}^{-1}\right)$ [64], it is obvious that significant differences arise for the indoor climate and the physical performance of the building envelope.

Political reactions to the topic have been made by the European Parliament in the Energy Performance of Buildings Directive (EPBD) [65], with increasing airtightness being cited as an essential issue for energy efficiency in buildings. For most European countries, the EPBD indicates a good airtightness as a requirement for near-zero energy buildings. Regulations for historic buildings (especially listed buildings) often allow exceptions or reduced requirements, the relevance of airtightness in historic buildings however is the same or even higher than in new buildings. The challenge is to find an adequate technical solution for ventilation with low detrimental impact and appropriate material compatibility, and which should consider the building envelope airtightness.

For this reason, as mentioned in the previous section "buildings physics", an overall conceptual design for the envelope renovation has to be examined. A successfully implemented example is the Villa Castelli [65] in Bellano, Italy. There, a rigorous and sophisticated refurbishment concept was implemented, and the air leakage was reduced from $\mathrm{n}_{50}=3.0$ to $0.41 \mathrm{~h}^{-1}$.

\section{Systematic Approach Proposal-Integrating Ventilation Measures in Historic Buildings}

\subsection{ATLAS Interreg Alpine Space and TASK 59-HiBERtool}

In order to support designers in the identification of potentially suitable measures, within the international projects ATLAS Interreg Alpine Space [26] and IEA-SHC Task59 [25], numerous examples have been documented, assessed, and made available in the HiBERtool (Historic Buildings Energy Retrofit Tool) [66]. Three criteria had to be met by measures to be included: technical viability/robustness/feasibility, improvement of energy efficiency, and taking into account the historical value of the building. Based on the examples, a series of decision trees (Figure 1) were developed which, via questions on the building's features and heritage values, guide the user and lead to the proposal of a range of possible 
measures. In this paper, we describe the methodology focusing on the integration of ventilation measures, which was not previously published.

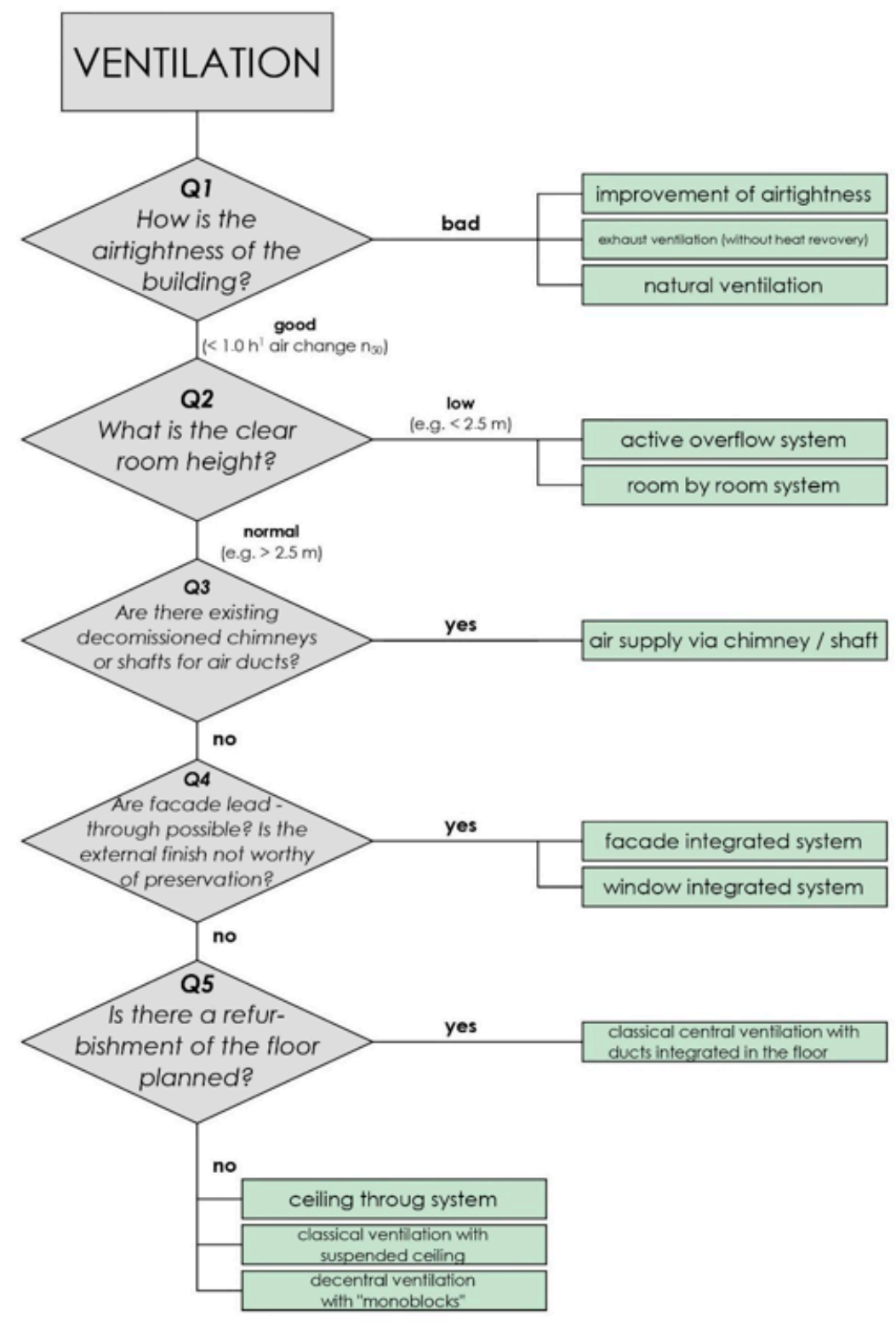

Figure 1. Decision tree for the implementation of ventilation systems in historic buildings.

In the case of ventilation, the first discriminating question is on the airtightness of the existing building. In case the existing airtightness is "low" (i.e., a $\mathrm{n}_{50}$ value above $1.0 \mathrm{~h}^{-1}$ ), three options are available: "improving the airtightness", "applying exhaust ventilation", or "natural ventilation". If the airtightness is better (i.e., a $n_{50}$ value below $1.0 \mathrm{~h}^{-1}$ ), or if the airtightness will be improved through the intervention, the next question concerns the room height: if below $2.5 \mathrm{~m}$, ductwork is difficult, and active overflow systems as well as room-by-room systems are proposed. If the room height is above $2.5 \mathrm{~m}$, ducting stays as an option. If the building has decommissioned chimneys or shafts, a solution for the ventilation-related use is described. A further distinction is given by the protection status of the facade. If new openings in the facade are possible, particularly if the windows do not have any historic value, integrated facade solutions and ventilation concepts which are integrated into windows are possible. The extent of the redevelopment work related to the floor construction results in different possible solutions. If refurbishment of the floor construction is intended, the distribution of the supply and exhaust air can be 
accommodated in the floor. If this is not the case, a ceiling-through system, so-called monoblocks, or a classical ventilation system with a suspended ceiling, are possible measures.

The HiBERtool contains several parton distribution functions of the various examples. In short texts, these examples (Figure 2) describe the relevant characteristics of the measure and provide links for further documentation of the solution approach. The user is provided with the necessary information to decide whether the measure, pre-selected by the HiBERtool as potentially compatible, is appropriate. This offers the significant advantage of an extensive and prompt search with the possibility of more detailed information. In the next step, the basic selection can be adapted to the application in a specific refurbishment case and can be assessed according to the methods described in Section 4.2.
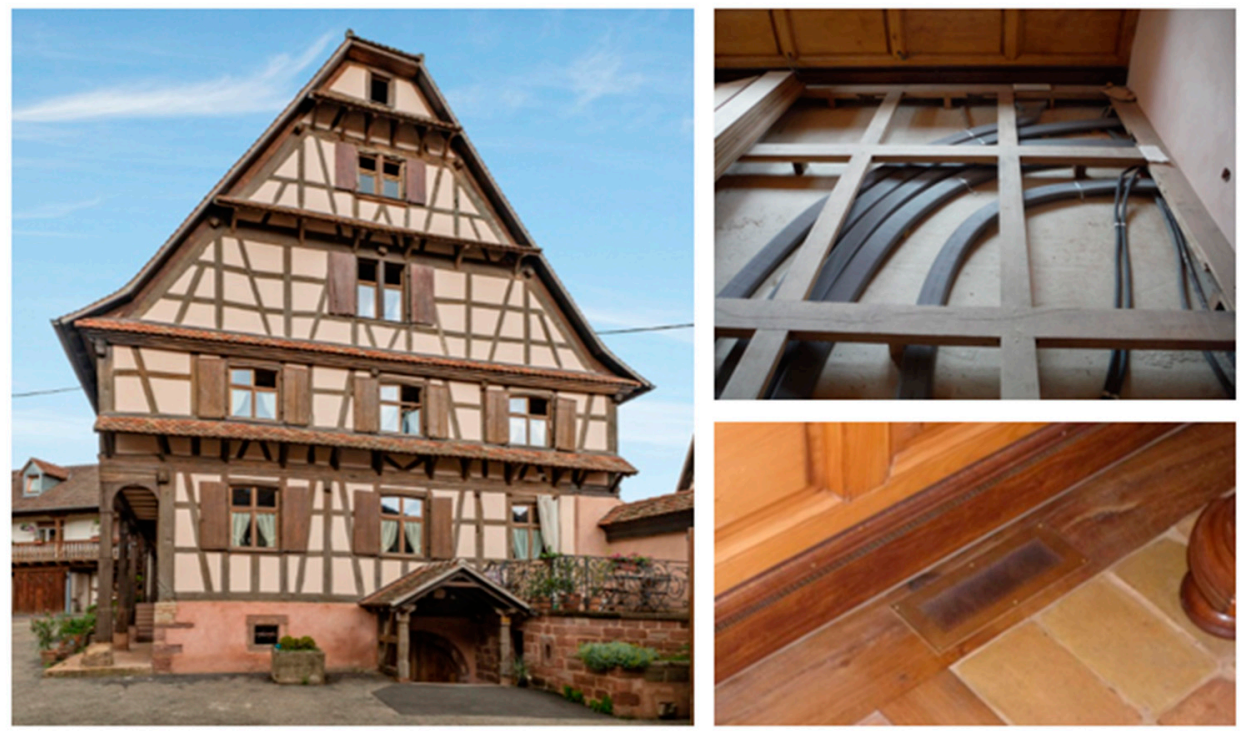

Figure 2. One of the documented examples. A timber-framed house from 1783 in Schnersheim, Alsace, France: Architecture, a "hidden" air supply, ventilation ducts of the HRV in the floor. Source: Denis Elbel.

\subsection{Approach from EN 16883-Assessment Criteria}

The European standard EN 16883:2017 [27] acts as a guideline for building owners, authorities, and professionals to apply the existing standards in the field of energy efficiency to the specific requirements of historic buildings. It proposes and describes a systematic procedure for improving energy performance of historic buildings and, in particular, the assessment and selection of the appropriate measures that match the requirements of the building in question. Section 10.3 of the standard proposes to compile a list of possible measures as a starting point. The output of the HiBERtool can be considered as such a list of potentially applicable measures after being first screened by experts (section 10.4 of the standard).

The next step is the assessment of the measure for the specific refurbishment case. For this purpose, the standard provides a number of assessment criteria in the following categories:

- $\quad$ Technical compatibility

- Heritage significance of the building and its settings

- Economic viability

- Energy

- Indoor environmental quality

- Impact on the outdoor environment

- Aspect of use

A measure is assessed on the specific building for each assessment criterion in a riskbenefit scheme with a scale ranging from -2 (high risk, red), over -1 (low risk, orange), 0 (neutral, white), and 1 (low benefit, light green), to 2 (high benefit, green), as shown 
in Table 1. This quick assessment thus results in a colored table, which allows for an immediate visual perception whether the measure achieves a high added value for the given criterion, has a neutral effect on it, or even represents a risk in a specific case.

Table 1. Assessment scale according EN 16883 [27].

\begin{tabular}{l|cccc}
\hline \multicolumn{5}{c}{ Assessment Scale } \\
\hline-2 High risk & -1 Low risk & 0 Neutral & 1 Low benefit & 2 High benefit \\
\hline
\end{tabular}

In the next step, after the pre-selection with the quick assessment (section 10.4 of the standard), an in-depth assessment of the measures (section 10.5 of the standard) is carried out, which is intended to contribute to the decision-making process.

\section{Practical Examples-Assessment According to EN 16883}

\subsection{Quick Assessment}

In order to carry out a quick assessment of a renovation measure, the framework conditions of the refurbishment must be precisely defined. With ventilation systems, these varying factors are easier to identify than with an evaluation of a wall solution. For example, the hygrothermal risks of ventilation systems are generally considered relatively low. Regardless of which ventilation system is installed, it has a positive effect on moisture removal and helps to minimize the hygrothermal risks of the building envelope. The different criteria should be seen as a checklist to consider all important aspects in connection with the renovation of historic buildings. Some solutions require a detailed consideration of a certain point which may be trivial to answer in another system.

To demonstrate the application of the standard and to show a structured process in the selection of refurbishment measures, three different measures are presented below (Tables 2-4) using the quick assessment method previously mentioned (Table 1). The big difference to the quick assessment specified in the standard is that a general assessment on the suitability of the measure in historic buildings is carried out and that the evaluation is not based on a specific object. The selected measures (in the Table 2 example) describe the general implementation of an "active overflow" system, a decentralized room-by-room through the facade ventilation system with constant airflow, as well as an alternative solution with natural ventilation.

The table of the measures provides a visual decision-making support tool to illustrate where the strengths and weaknesses of the measures are. The tool helps visualize the assessment trend of the individual categories. Since the solutions listed are refurbishment measures without specific renovation cases, different factors are described in the respective criteria and different variants are evaluated as possible considerations. A case-specific general evaluation of ventilation systems is not possible within the assessment standard because the assessment would depend on the characteristics of a specific building. For ventilation systems, this issue is mainly related to the criterion "Heritage significance of the building and its settings" as many variations will exist due to unique circumstances. For this reason, Table 2 is supplemented by Table 3 (active overflow system) and Table 4 (decentral room-by-room ventilation), which also include characteristics of the building stock in the assessment. Tables 3 and 4 are essentially a matrix representation of the decision tree previously shown. For this reason, it is also evident that the decision-making approach can be roughly limited by the questions within the decision tree. 
Table 2. General quick assessment for (a) natural ventilation, (b) active overflow, and (c) decentral mechanical ventilation according the assessment criteria of EN 16883:2017.

\begin{tabular}{|c|c|c|c|}
\hline Assessment Criteria EN16883:2017 & Natural Ventilation & Active Overflow & $\begin{array}{c}\text { Decentral Room-by-Room } \\
\text { Ventilation }\end{array}$ \\
\hline \multicolumn{4}{|l|}{ Technical Compatibility } \\
\hline \multirow{2}{*}{\multicolumn{4}{|c|}{$\begin{array}{c}\text { Hygrothermal risks } \\
\text { Biological risks }\end{array}$}} \\
\hline & & & \\
\hline \multicolumn{4}{|l|}{$\begin{array}{l}\text { Robustness/Buildability/design/ } \\
\text { Application }\end{array}$} \\
\hline \multicolumn{4}{|l|}{ Thermal bridges/Connection } \\
\hline \multicolumn{4}{|c|}{\begin{tabular}{l|l} 
Reversibility & \\
\end{tabular}} \\
\hline \multicolumn{4}{|c|}{ Heritage significance of the building and its settings } \\
\hline \multicolumn{4}{|c|}{\begin{tabular}{l|l} 
Material, constructional and structural impact & \\
\end{tabular}} \\
\hline \multirow{2}{*}{\multicolumn{4}{|c|}{$\begin{array}{c}\text { Architectural, aesthetic, visual impact } \\
\text { Spatial impact }\end{array}$}} \\
\hline & & & \\
\hline \multicolumn{4}{|l|}{ Economic viability } \\
\hline \multirow{2}{*}{\multicolumn{4}{|c|}{$\begin{array}{c}\text { Capital costs } \\
\text { Operating costs, including maintenance costs }\end{array}$}} \\
\hline & & & \\
\hline \multicolumn{4}{|l|}{ Economical return } \\
\hline \multicolumn{4}{|l|}{ Economic savings } \\
\hline \multicolumn{4}{|l|}{ Energy } \\
\hline \multicolumn{4}{|l|}{$\begin{array}{l}\text { Energy performance and operational energy } \\
\text { demand in terms of primary energy rating } \\
\text { (total), primary energy rating (non-renewable), } \\
\text { primary energy rating (renewable) }\end{array}$} \\
\hline \multicolumn{4}{|l|}{$\begin{array}{l}\text { Lifecycle energy demand in terms of use of } \\
\text { renewable primary energy and non-renewable } \\
\text { primary energy }\end{array}$} \\
\hline \multicolumn{4}{|l|}{ Indoor environmental quality } \\
\hline \multicolumn{4}{|l|}{$\begin{array}{l}\text { Indoor environmental conditions suitable for } \\
\text { building content preservation }\end{array}$} \\
\hline \multicolumn{4}{|l|}{$\begin{array}{l}\text { Indoor environmental conditions suitable for } \\
\text { building fabric preservation }\end{array}$} \\
\hline \multicolumn{4}{|l|}{$\begin{array}{l}\text { Indoor environmental conditions suitable for } \\
\text { achieving good occupant comfort levels }\end{array}$} \\
\hline \multirow{2}{*}{\multicolumn{4}{|c|}{ Emission of other harmful substances }} \\
\hline & & \multicolumn{2}{|c|}{ Impact on the outdoor environment } \\
\hline \multicolumn{4}{|l|}{$\begin{array}{l}\text { Greenhouse gas emissions from measures } \\
\text { implemented and operation }\end{array}$} \\
\hline \multicolumn{4}{|l|}{ Emission of other harmful substances } \\
\hline \multicolumn{4}{|l|}{ Natural resources use } \\
\hline \multicolumn{4}{|l|}{ Aspect of use } \\
\hline \multicolumn{4}{|l|}{$\begin{array}{l}\text { Influence on the use and the users of } \\
\text { the building }\end{array}$} \\
\hline Consequences of the change of use & & & \\
\hline $\begin{array}{l}\text { Ability of building users to manage and } \\
\text { operate control systems }\end{array}$ & & & \\
\hline
\end{tabular}

Table 3. Quick assessment of "Heritage significance of the building and its settings" in relation to existing buildings - active overflow system.

\section{Heritage Significance of the Building and Its Settings-Active Overflow System}

Material, constructional and Architectural, aesthetic, visual structural impact impact

Spatial impact

How is the airtightness of the building?

$$
\begin{aligned}
& \mathrm{n}_{50}<1.0 \mathrm{~h}^{-1} \\
& \mathrm{n}_{50}>1.0 \mathrm{~h}^{-1}
\end{aligned}
$$

Room height

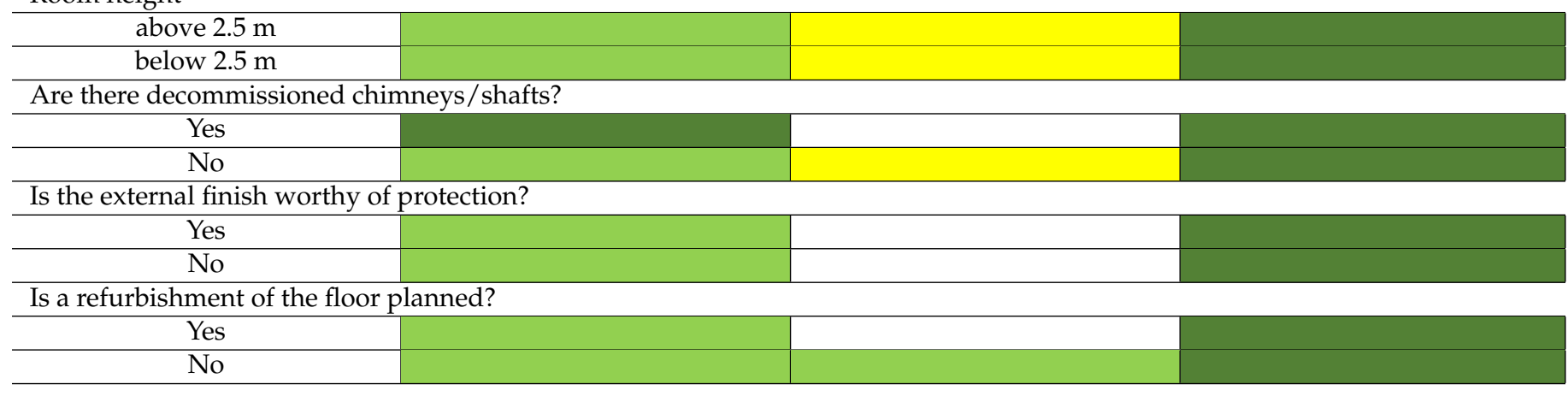


Table 4. Quick assessment of "Heritage significance of the building and its settings" in relation to existing buildings decentralized room-by-room ventilation.

Heritage Significance of the Building and Its Settings-Decentralized Room-by-Room Ventilation.

\section{Material, constructional and Architectural, aesthetic, visual} structural impact
Spatial impact

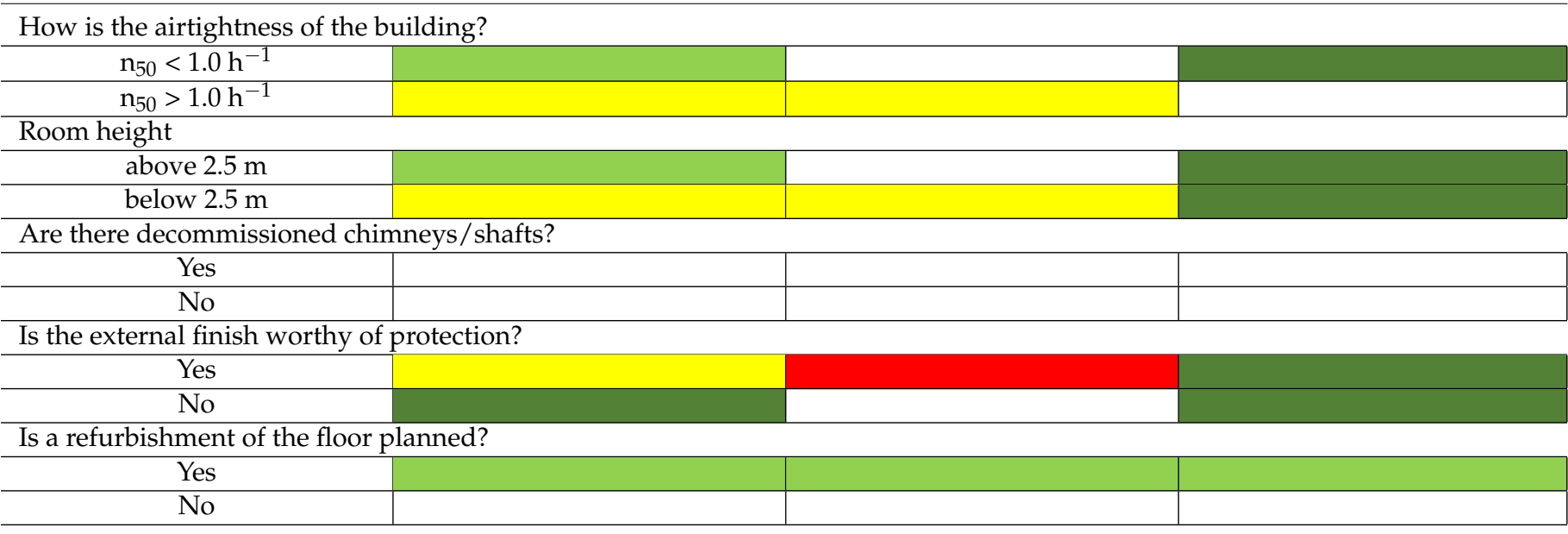

\subsubsection{Natural Ventilation}

To explain the topic of energy efficiency of natural ventilation and justify its inclusion in this paper, a more detailed description of a possible natural ventilation system in warmer climates is described in the following.

Natural ventilation, air movement generated by air pressure differences between indoor and outdoor, is controlled by openings on the building enclosure such as windows, doors, and vents (Figure 3). Differing from air leakage, natural ventilation is the intentional passive transfer of air directed through openings of the facade and/or roof of the building. Determining the opening direction and total opening area is the subject of design for natural ventilation systems in order to obtain the best benefit from local and seasonal breezes.

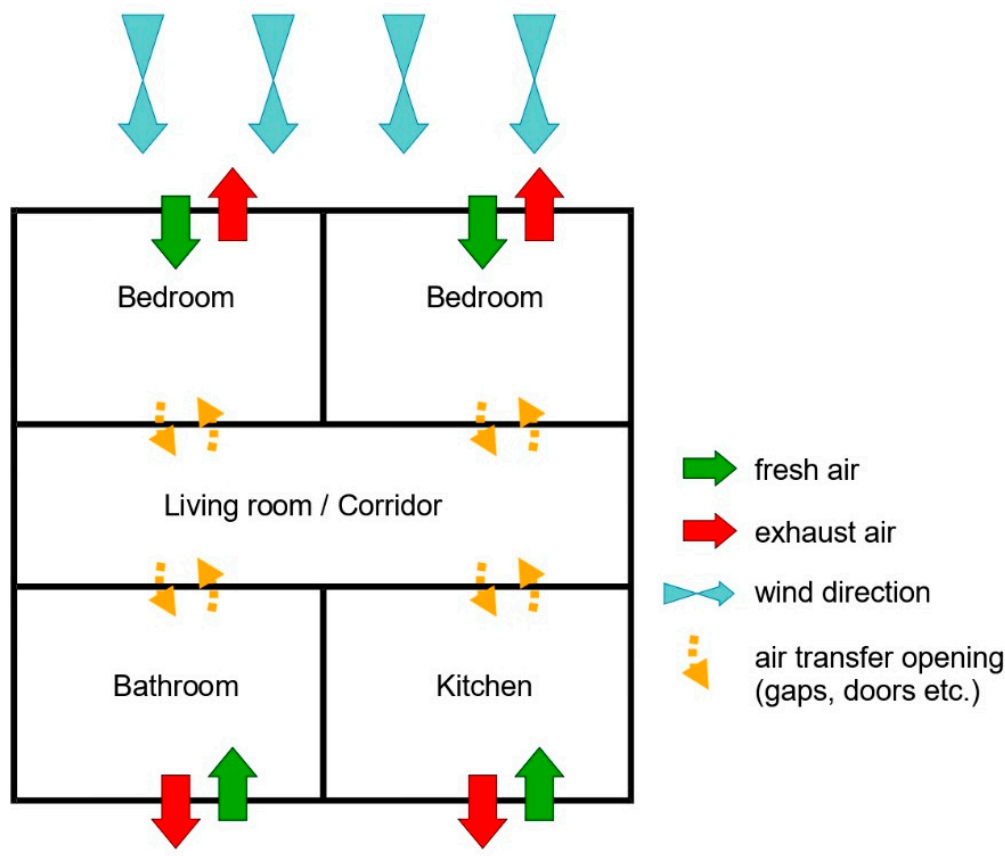

Figure 3. Scheme of natural ventilation. 
Natural ventilation systems have provided a traditional means of indoor climate control that has been used widely in historic buildings $[67,68]$. The continued use of natural ventilation solutions minimizes interventions in historic building restorations and supports conservation of the heritage significance of buildings with minimum disturbance.

The manual control strategy based on long-term local experience of users is mostly enough to operate the building, yet at the same time, it hosts hygrothermal and biological risks. The manual control strategy can lead to thermal bridge occurrences in the case of unexpected climate changes and faulty control strategies by the building users. Even if natural ventilation is one of the key user-driven passive techniques, it may not always be guaranteed due to high levels of noise, concerns about security, air pollution, and adaptive reuse of buildings and changing urban density $[69,70]$.

In colder climates, the utilization of natural ventilation systems may increase heat losses and energy costs, while in temperate climates, it contributes to heat rejection, economic savings, and better thermal comfort $[69,71]$. Therefore, the geographical location and local microclimate are the key factors influencing decision-making for improving energy performance of historic buildings when considering natural ventilation.

In addition, with the aim of conservation of finite natural resources and minimizing environmental load, ventilation of historic buildings through local/seasonal winds provides the additional benefit of reducing a building's carbon footprint and pollutants to the atmosphere [72].

\subsubsection{Active Overflow Systems}

In the concept of active overflow openings, the supply fresh air ductwork is limited to one room, the so-called "mixed air room" (Figure 3). From this fresh air reservoir, which can be the corridor or the living room, depending on the floor plan, the fresh air is transported to the bedrooms by means of an active transfer (mechanically generated overflow with fans). The active transfer can be installed in the partition walls or directly in the room door panels. The air can flow back into the mixed air zone via passive overflow openings (for example the slot under the door panel). In the case of leaky buildings (often the case for historic buildings), it is recommended not to blow fresh air from the "mixed air room" into the bedrooms. Instead, the exhaust air should be extracted from the bedroom and the fresh air should flow in through passive overflow openings (Figure 4). Blowing in can cause overpressure in the bedrooms and moist warm air can be forced into the construction, which can lead to condensation and damage.

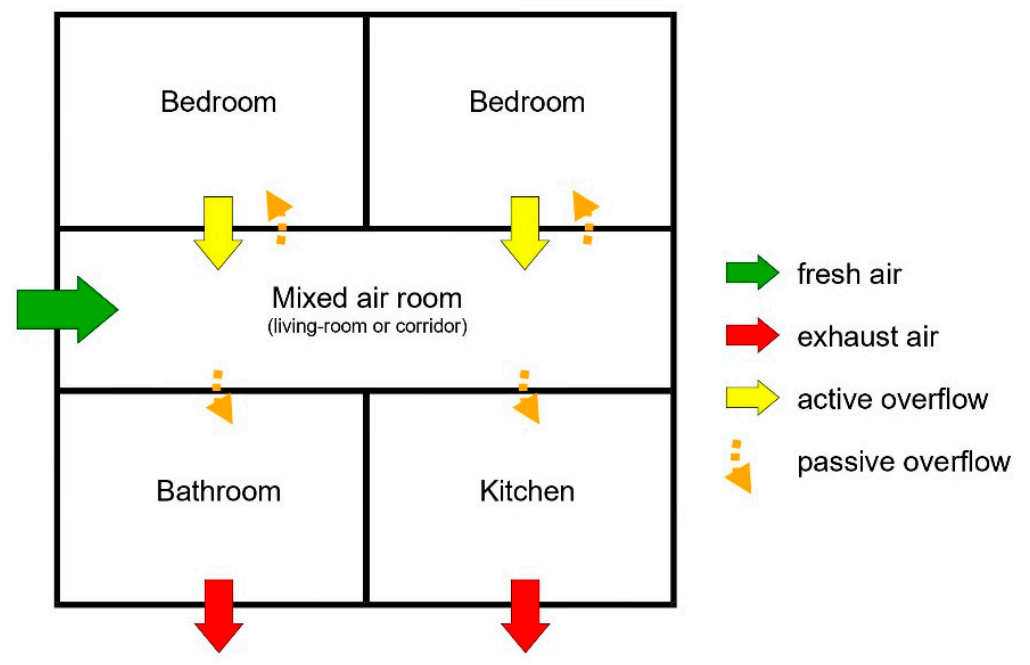

Figure 4. Scheme of the active overflow system according to Reference [73].

In rooms with high levels of humidity, pollutants, and odors (e.g., toilet and kitchen), the exhaust air is extracted and connected to the central ventilation unit [73]. It can be 
combined with heat recovery, as demonstrated in a school in Innsbruck, Austria, during the EU-project SINFONIA [74].

The advantage in terms of space savings through the elimination of supply air ducts was demonstrated in the city of Zurich in 2010. There, a design competition for products that use the principle of active transfer led to the development and launch of numerous active transfer products [75].

The concept has been implemented in several buildings and its function and feasibility has been confirmed. The system has been successfully implemented in non-residential buildings [76] as well as in historic buildings such as the Brünnengut manor house in Bern, Switzerland (Figure 5).
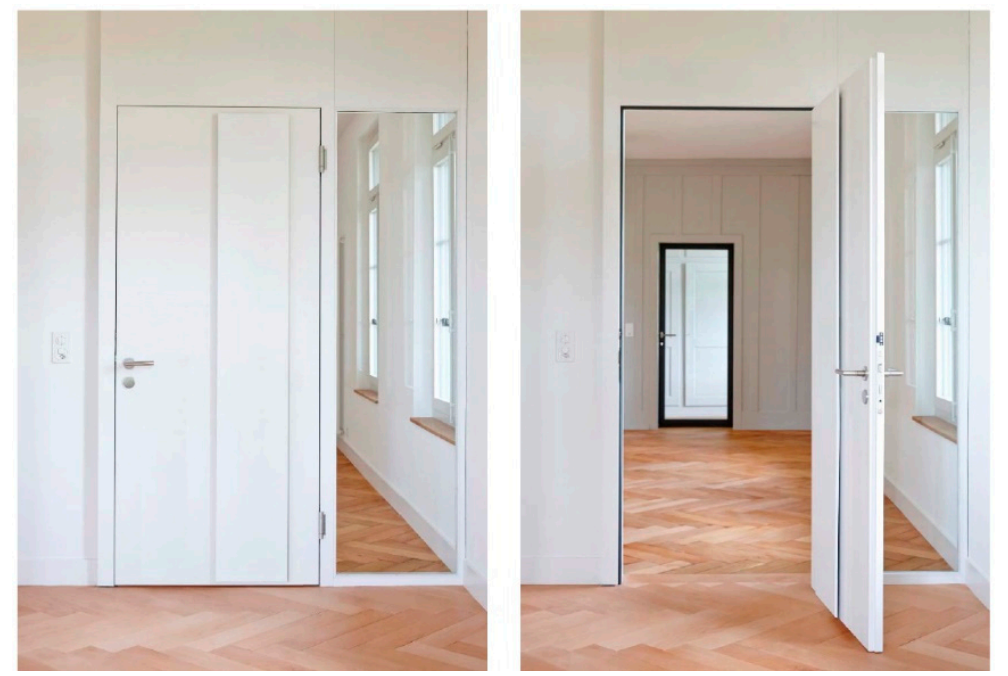

Figure 5. Active overflow system as a so-called "Verbundlüfter" by the company Erich Keller integrated into the door leaf in the listed manor house Brünnengut in Bern (Switzerland).

In the case of active overflow systems, it is clear that the strengths lie in the spatial, tectonic, and structural impacts. Buildings with low airtightness make the implementation of a solution more complex, often requiring protection of internal facades to mitigate elevated moisture accumulation risks. Furthermore, the solution is relatively neutral in terms of visual impact and is highly dependent on the particular characteristics of the building. Most of the other assessment criteria are positively influenced.

\subsubsection{Decentralized Room-by-Room Ventilation Through the Facade with Constant Airflow}

Mechanical ventilation with heat recovery, as opposed to natural ventilation, has the added benefit of recovering some of the heat that would have otherwise been lost. Typical system efficiencies range from $75 \%$ to $95 \%$ heat recovery. Experimental testing has demonstrated very high efficiencies [77] that has also been confirmed with installations in existing multi-family residential buildings [78]. For historic buildings, which often utilize natural ventilation (making it difficult to control airflow), installing mechanical ventilation with heat recovery can significantly improve indoor climate conditions and reduce energy use [79].

In a decentralized solution, a ventilation unit is placed in each apartment (Figure 6). There are several different possibilities for decentralized solutions. The following description deals with decentralized room-by-room ventilation through the facade with constant airflow. 


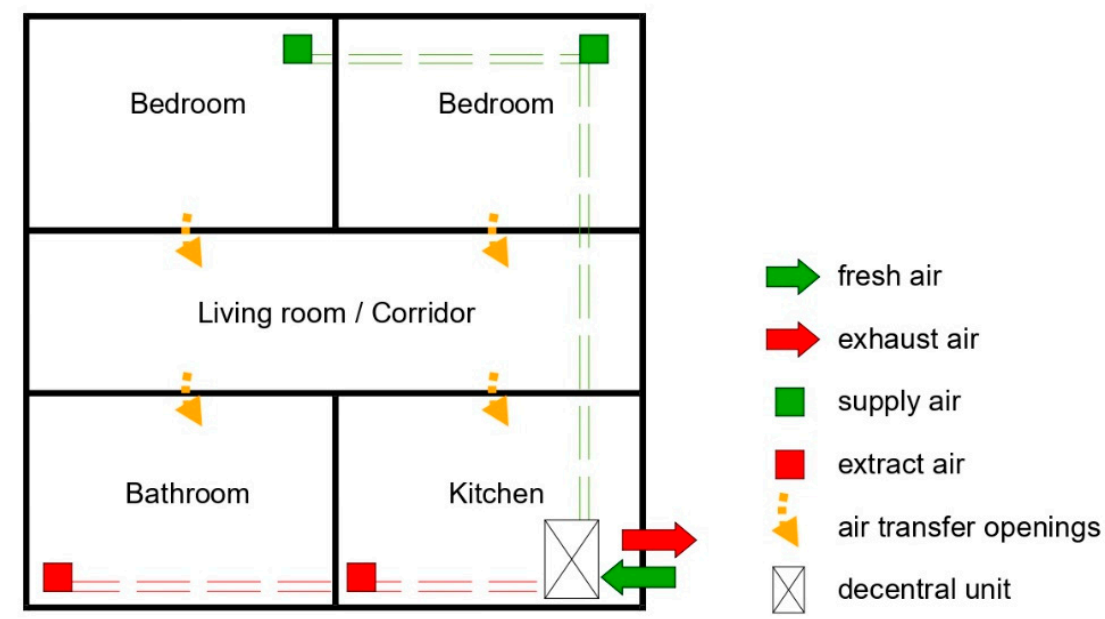

Figure 6. Scheme of the decentralized room-by-room ventilation.

The solution implements a full individual ventilation system in each flat with inlet and outlet through the facade and heat recovery inside each unit. The system can also work as a hybrid solution, where the mechanical ventilation is stopped during summer, resulting in lower electricity consumption compared to a full-year operation. The lower electricity consumption comes partly from the short ducts and partly from the summer stop. Concerning cooling, e.g., during summer months, natural ventilation is a much better option than mechanical ventilation.

During winter, the ventilation systems are controlled individually by the moisture content in each flat, though with a minimum airflow to ensure adequate fresh air in the indoor climate. As an example, in Denmark, the minimum required fresh airflow is $0.3 \mathrm{~L} / \mathrm{s}$ per $\mathrm{m}^{2}$ floor space, equal to approximately 0.5 air changes per hour.

As mentioned, it is possible during the summer that natural ventilation through window openings is used instead and the mechanical system is only turned on by occupancy sensors in the bathroom and if the cooker hood (integrated with the building ventilation system) is turned on. The latter needs a dispensation from the local building authorities in many countries.

The technology is based on innovative components reducing noise, optimizing airflow, and recovering heat in a compact design.

There are a lot of different solutions for heat recovery [80], but for residential buildings, typically, fixed plate exchangers are used. Ventilation with heat recovery is particularly relevant to consider in the following situations:

- If mold has occurred in the apartment (may often be due to lack of ventilation),

- In connection with energy renovations, for example facade renovation and window replacement,

- In cold climate, where draft problems can occur.

Decentralized ventilation is often used in situations where the space for ducts throughout the building is limited and there are no existing ducts. From a heritage point of view, the solution can, however, be problematic since exhausts and inlets will typically have to be done through the facade. However, sometimes it is possible to have these openings through the building envelope in areas that are not considered culturally protected, e.g., gables or generally unseen portions at the back of the building.

\subsection{Detailed Assessment-Active Overflow System}

In this section, the assessment of an active overflow system is demonstrated and examined in detail using a fictitious refurbishment case as an example. Due to the wealth of information that is requested in the course of a detailed assessment, it is necessary to relate the information to a specific case. In the course of IEA SHC Task 59 [25], the criteria 
of the standard have been specified in detail in order to conduct a detailed assessment of the individual topics. The aim is to show how the assessment criteria should be applied and to convey the scope of such a detailed assessment. Furthermore, the differences with the quick assessment will be illustrated.

The fictitious refurbishment case is represented by a farm building in Tyrol from the 18th century (Figure 7). Shortly after the end of the Second World War, a cellar was built. The entire farm was built with timber block construction (log walls) and has an average room height of $2.40 \mathrm{~m}$ in the living rooms. The attic is not a finished living space and contains roof trusses within an unconditioned space. The building is not a listed building but is subject to local heritage protection of the village. In order to enable contemporary use, the building will be thermally upgraded. Due to the protection of the historic appearance of the village, the external appearance of the building is not allowed to be changed. In order to guarantee at least a room height of $2.40 \mathrm{~m}$ and thus maintain the parapet heights of the windows and the external appearance, the wooden ceilings are only structurally strengthened and not extended by any additional depth in the floor construction. In the following sections, the criteria mentioned in EN 16883:2017 [27] are assessed in detail.

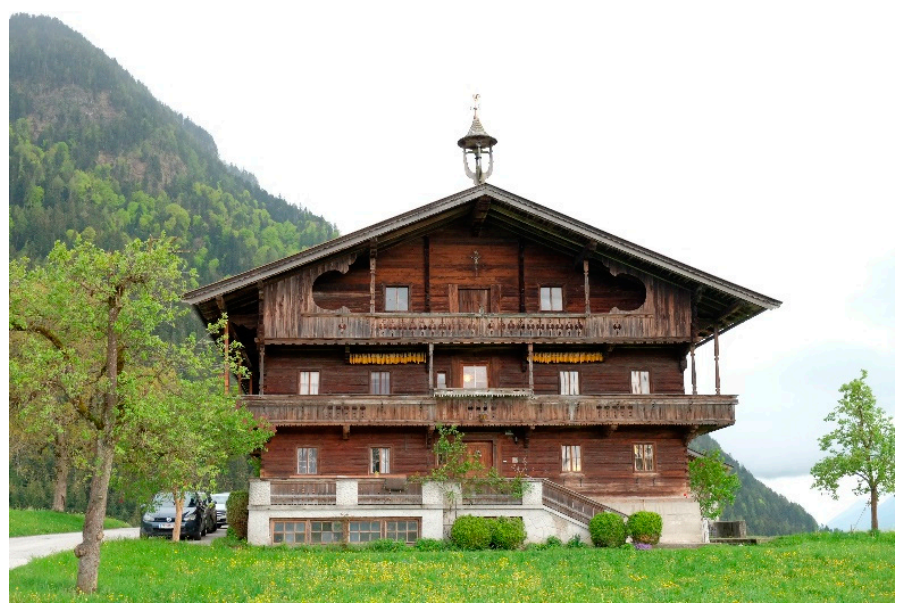

Figure 7. Similar farmhouse in Tyrol as described in the fictional example. Source: Alexander Rieser.

\subsubsection{Technical Compatibility}

The category "technical compatibility" assesses the solution for various risks in connection with the building structure and feasibility.

Hygrothermal risks: Ventilation generally has a positive influence on the structure and materials of a historical building. Excess moisture loads are removed through the exchange of air. Like any other classical ventilation system, the active overflow system also has to ensure the required air exchange in order to achieve the desired relative humidity. With an active overflow system, the exchange of air between rooms must be implemented. This can be achieved by leaving the interior doors open or by increasing the air flow rate through active transfer. However, the system must be designed to ensure that no significant overpressure is created in ventilated rooms by the overflow fans. As a result, moist warm air could penetrate the construction via leaks, condense, and cause damage. To avoid this, the flow direction of the active overflow should be chosen from the room to the mixed air room.

Biological risks: Depending on the design and construction, biological risks can arise from the above-mentioned overpressure. In the case of the wooden construction, presented in this example, special attention must be paid in this regard. Through the thermal refurbishment of the external walls, a higher airtightness level is achieved, which must be verified by a blower door test.

Robustness/buildability/design/application: Due to the typical arrangement of the rooms of agricultural buildings in Tyrol, the corridor is well-suited to be used as a distribu- 
tion zone, the so-called "mixed air room" (Figure 8). The main access for fresh air is from the attic via the existing chimney of the smokehouse. The installation of the active overflow units must be coordinated with the appearance and structure but can be integrated into the interior doors and in the internal log walls. For this reason, no special structural knowledge or conservation skills are required, but a certified system should be selected for the overflow units.

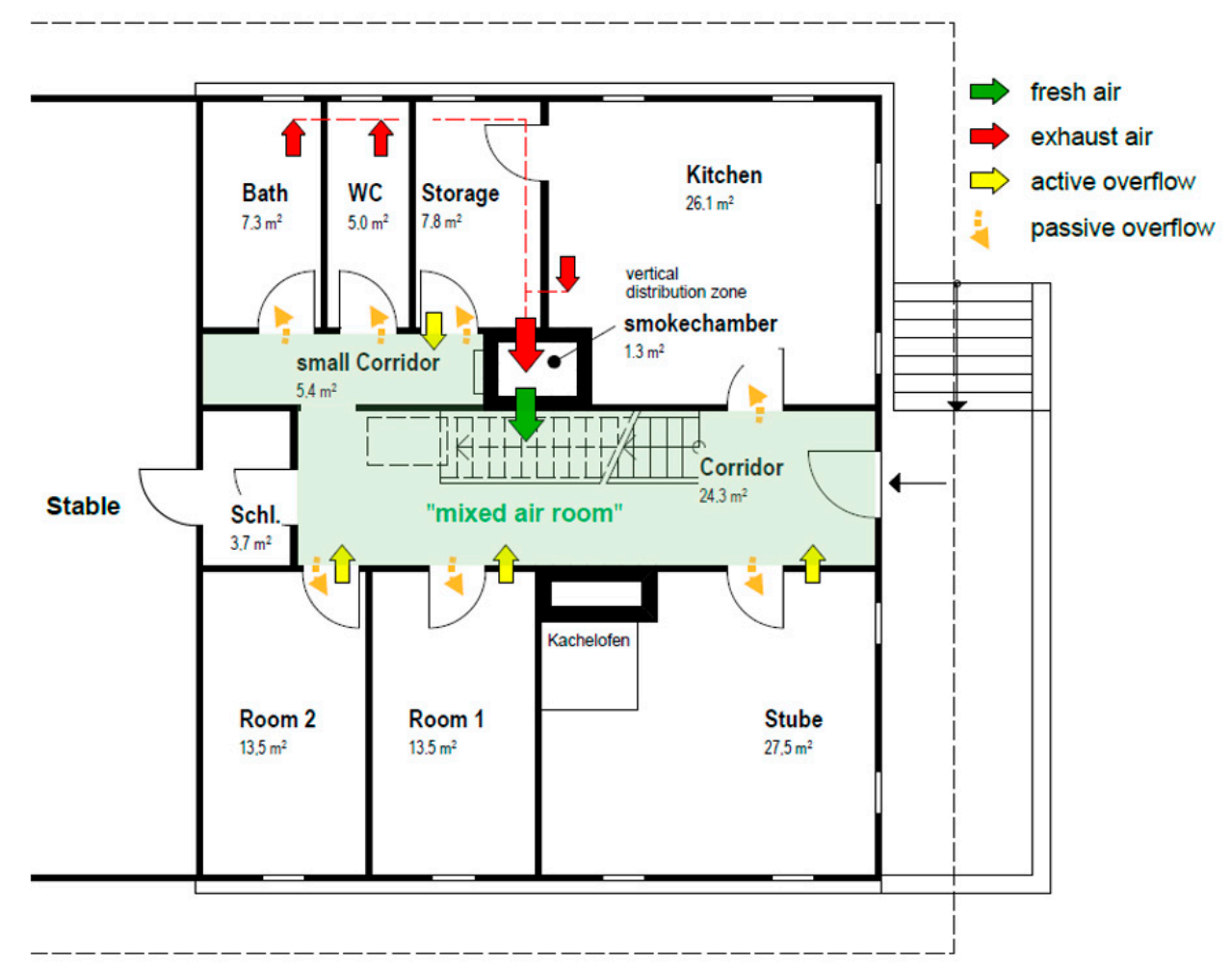

Figure 8. Example of an active overflow system based on a typical floor plan in Tyrolean farms. The vertical distribution of the air takes place via the continuous former smoke chamber.

Thermal bridges/connection: Due to the installation of the ventilation unit in the unconditioned attic, no thermal bridges are created by the penetration of the insulated ceiling.

Reversibility: The system is not completely reversible due to the penetrations made for piping of the supply and exhaust air channels and the openings for the active overflow units.

\subsubsection{Heritage Significance of the Building and Its Settings}

Different impacts of the building's materials, appearance, and proportions regarding aspects of historic preservation are investigated.

Material, tectonic, structural impact: The active overflow system has a minimal impact on the structure of the existing building. Penetrations for supply and exhaust air must be taken into account. The fans of the overflow system require a power connection which must be hidden within the wooden walls. Possibilities for this are the placement of cables in the skirting boards as well as a hidden routing of the cables in the door frames.

Architectural, aesthetic, visual impact: This solution is particularly beneficial from an architectural point of view. Only one air supply opening for the ventilation unit is required on the facade. This opening can be integrated into the facade in different ways, such as hidden by wooden grilles in the ridge region. In the northern hemisphere, care must be taken to install the air intake opening on the north facade to avoid the intake of very warm air in the summer months. Due to the limited number of supply and exhaust air openings, with proper design attention, there are hardly any visual impairments (Figure 9). Thus, 
these openings must be included in the refurbishment concept in order to be installed such that they are as hidden as possible. The primary challenge is the integration of the active overflow units. However, there are a number of solutions to integrate them into the design concept while maintaining the historic fabric. Various solutions to integrate the units in walls and doors are available on the market. In the example of a historic farmhouse, the fans can be integrated quite well into wooden log walls. Old wood covers can be integrated into the architectural concept. Noise protection should also be considered.

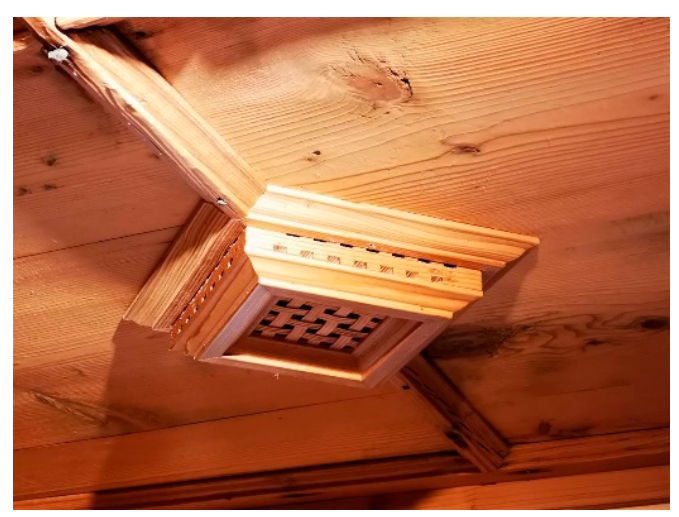

Figure 9. Integration of an exhaust air opening in a typical suspended wooden ceiling as commonly found in Tyrolian farms. Source: Michael Flach. Spatial impact: Starting with the vertical hidden piping in the existing chimney, a solution for the air supply openings must be considered. Flat ducts can be integrated between the beams of the wooden ceiling and hidden by a second wooden cover at the bottom to match the look of the existing wooden soffit. An air intake opening coming directly from the unused chimney of the smoking chamber would also be a possibility if it is concealed by a suitable wooden grille.

\subsubsection{Economic Viability}

Capital costs: Due to reduced supply air ductwork, less silencers, and supply air inlets, the capital costs are low for a mechanical ventilation system.

Operating costs, including maintenance costs: The total electricity costs of the active overflow system are approximately $20-30 \%$ higher, depending on the floor plan configuration, compared to a standard heat recovery system. The reason is the higher flow rate for the mixed air zone (only partly compensated by the lower pressure drop of the supply air duct system) [73] (p. 77).

Economical return and savings: Economically, there is almost no significant savings when compared to the existing building before refurbishment, the advantage is the reduced visual impact on the historic building while increasing comfort and IEQ. The main savings with mechanical ventilation are in the recovery of heat, although this by itself would not justify the investment costs from an economic point of view. The topic of mechanical ventilation must be considered within the context of other points of evaluation such as heritage value, which cannot be easily quantified in terms of economic costs. By integrating active ventilation, the indoor comfort is increased and the damage potential due to moisture accumulation in the building is reduced.

\subsubsection{Energy}

The higher the air exchange rate through active transfer, the lower the global air exchange rate (air exchange rate of outdoor air and indoor air) of the system can be. This should be taken into account especially in the winter months as too high of a global air exchange rate can result in air that is too dry. Due to the higher air exchange rates used in active transfer, a higher energy demand results from the fans. By installing a heat recovery system, the ventilation system provides a considerable contribution to improving the energy efficiency of the building. 


\subsubsection{Indoor Environmental Quality}

Indoor environmental conditions suitable for building content preservation: In the example case, there are no special objects, paintings, or other furnishings that require very controlled climate conditions.

Indoor environmental conditions suitable for building fabric preservation: Thanks to the new ventilation system, high moisture loads in the building can be controlled and avoided. Especially in combination with internal insulation, this ventilation solution represents a decisive advantage and is recommended due to the increased air tightness resulting from the refurbishment measures.

Indoor environmental conditions suitable for achieving good occupant comfort levels: This point can be answered in general terms. The controlled air exchange not only removes excess moisture from the rooms but also other indoor air pollutants such as particle matter, VOCs (Volatile Organic Compounds), and radon.

Emission of other harmful substances: There are no risks to be expected with regular maintenance of the filters and the system. Harmful substances from indoor air are diluted by the mixing of fresh air controlled by the air exchange rate.

\subsubsection{Impact on the Outdoor Environment}

The heat recovery system saves energy, which has a direct positive effect on the $\mathrm{CO}_{2}$ balance of the building. The installation of a ventilation system also makes sense in order to improve the function and durability of the building.

\subsubsection{Aspect of Use}

Influence on the use and the users of the building: As the general name of a comfort ventilation system suggests, ventilation increases the living comfort for the user. It is no longer necessary for the user to manually ventilate several times a day and hygienic air quality is also maintained at night.

Consequences of the change of use: The fans can cause noise pollution at high air exchange rates. For this reason, the maximum airflow rates through active transfer of $70 \mathrm{~m}^{3} / \mathrm{h}$ per room must be observed. Up to this airflow limit, a sound level of below or equal to $23 \mathrm{~dB}(\mathrm{~A})$ can be guaranteed [73].

Ability of building users to manage and operate control systems: The ventilation system must be correctly adjusted according to the number of occupants. The more people there are in the building, the higher the air exchange rate must be (at least $30 \mathrm{~m}^{3} / \mathrm{h} /$ person). Maintenance work such as filter exchange of the ambient air supply or extract air filters must be carried out by the occupant.

\section{Discussion and Conclusions}

Ventilation in historic buildings is a key parameter in terms of enhancing comfort and health for the inhabitants as well as for the conservation of the building structure by avoiding damage caused by moisture accumulation. Moreover, using well-controlled energyefficient ventilation strategies as heat recovery ventilation (HRV) or demand-controlled ventilation (DCV) will reduce the energy consumption significantly.

Compared to new buildings, ventilation in historic buildings should be planned, installed, and controlled not only respecting the needs of the inhabitants, but also the historic value of the building and its artistic and cultural heritage. This requires a highly interdisciplinary effort including all involved professions and disciplines, hence requiring a strong need for systematic guidelines.

An assessment of different measures and variants according to the standard EN 16883:2017 [27] can help to find the best solutions for individual cases of renovation and conservation of historic buildings. As the standard was written in general for all types of measures, the use of the criteria calls for more specific information and guidelines when it comes to particular decisions in terms of ventilation. 
Within the Interrreg Alpine Space project ATLAS [26] and TASK 59 [25], a so-called HiBERtool (Historic Buildings Energy Retrofit Tool) [66] has been developed as a systematic approach to have a first pre-selection of measures, which can work in terms of preservation, buildings physics, and technical feasibility. If the user of the tool wants to be more informed about practical implementation in real cases, links to a special database of historic buildings, the so called HiBERatlas [81], will give guidance via realized examples and reference buildings, with detailed documentation, photos, and illustrations.

In order to get a more accurate pre-selection and overview of the suitability of the respective measures focusing on ventilation, the quick assessment proposed in EN16883:2017 [27] was extended with the contents of the decision tree from the HiBERtool [66]. We demonstrated and proposed in this paper a way to get an overview of measures for the ventilation of historical buildings in general.

In order to assess the generally evaluated measures in detail on the basis of a specific renovation case, the assessment criteria of the standard were adapted to the topic of ventilation in the course of the above-mentioned projects, and the ventilation measure "active overflow systems" was applied practically for a specific fictitious example building in the course of the paper. During the application, the complexity of renovation measures for historic buildings was deliberately demonstrated. In practical application, the adapted criteria are intended to serve as a rough checklist for designers and consultants and should promote an increased awareness of the necessity of ventilation systems in historic buildings.

Author Contributions: Conceptualization, A.R., A.T., D.H.-A., K.E.T., J.R. and Z.D.A.; methodology, A.R., R.P., A.T., D.H.-A., K.E.T., J.R., Z.D.A., and G.G.A.; validation, A.R., R.P., A.T., D.H.-A., K.E.T., J.R., Z.D.A., and G.G.A.; writing-original draft preparation, A.R., R.P., A.T., D.H.-A., K.E.T., J.R., Z.D.A., G.K., and G.G.A.; writing-review and editing, A.R., R.P., A.T., D.H.-A., K.E.T., J.R., Z.D.A., G.G.A. and D.C.; visualization, A.R.; supervision, A.R., R.P., A.T., and D.H.-A.; project administration, A.R., R.P., A.T., and D.H.-A.; funding acquisition, A.R., R.P., A.T., and D.H.-A. All authors have read and agreed to the published version of the manuscript.

Funding: The authors wish to express their gratitude to the IEA-SHC and EBC Executive Committees for supporting the Task59/Annex76. The authors are especially grateful for the financial support from the European Regional Development Fund under the Interreg Alpine Space programme to the Project ATLAS (ID: ASP644) and the Swedish National Agency under the E2B2 programme. The authors also wish to thank all the experts in the Task59/Annex76 for their valuable contributions.

Institutional Review Board Statement: Not applicable.

Informed Consent Statement: Not applicable.

Data Availability Statement: Not applicable.

Acknowledgments: The Danish authors would like to acknowledge the Danish Energy Agency for funding participation in the IEA SHC Task 59 project.

Conflicts of Interest: The authors declare no conflict of interest. The funders had no role in the design of the study; in the collection, analyses, or interpretation of data; in the writing of the manuscript, or in the decision to publish the results.

\section{References}

1. Cantin, R.; Burgholzer, J.; Guarracino, G.; Moujalled, B.; Tamelikecht, S.; Royet, B.G. Field assessment of thermal behaviour of historical dwellings in France. Build Environ. 2010, 45, 473-484. [CrossRef]

2. Coillot, M.; El Mankibi, M.; Cantin, R. Heating, ventilating and cooling impacts of double windows on historic buildings in Mediterranean area. Energy Proc. 2017, 133, 28-41. [CrossRef]

3. Etheridge, D. A perspective on fifty years of natural ventilation research. Build. Environ. 2015, 91, 51-60. [CrossRef]

4. Khan, N.; Su, Y.; Riffat, S.B. A review on wind driven ventilation techniques. Energy Build. 2008, 40, 1586-1604. [CrossRef]

5. Bülow, A.E. Preventive Conservation for Paper-Based Collections in Historic Buildings. Ph.D. Thesis, De Montfort University, Leicester, UK, 2002.

6. Sahin, C.D.; Coşkun, T.; Arsan, Z.D.; Gökçen Akkurt, G. Investigation of indoor microclimate of historic libraries for preventive conservation of manuscripts. Case study: Tire Necip Paşa library, İzmir-Turkey. Sustain. Cities Soc. 2017, 30, 66-78. [CrossRef]

7. Durier, F.V. (Ed.) Trends in the French Building Ventilation Market and Drivers for Change; AIVC: Kyoto, Japan, 2008. 
8. Wouters, P.; Heijmans, N.; Delmotte, C.; Van Den Bossche, N.; Wuyts, D. Trends in the Belgian Building Ventilation Market and Drivers for Change; AIVC: Kyoto, Japan, 2008.

9. Kolokotroni, M. Trends in the Building Ventilation Market in England and Drivers for Change; AIVC: Kyoto, Japan, 2008.

10. Sherman, M. Trends in the US Building Ventilation Market and Drivers for Changes; AIVC: Kyoto, Japan, 2008.

11. Mélois, A.B.; Moujalled, B.; Guyot, G.; Leprince, V. Improving building envelope knowledge from analysis of 219,000 certified on-site air leakage measurements in France. Build. Environ. 2019, 159, 106145. [CrossRef]

12. Carrilho da Graça, G.; Linden, P. Ten questions about natural ventilation of non-domestic buildings. Build. Environ. 2016, 107, 267-273. [CrossRef]

13. Schulze, T.; Eicker, U. Controlled natural ventilation for energy efficient buildings. Energy Build. 2013, 56, 221-232. [CrossRef]

14. Cardinale, N.; Ruggiero, F. A case study on the environmental measures techniques for the conservation in the vernacular settlements in Southern Italy. Build. Environ. 2002, 37, 405-414. [CrossRef]

15. Kunkel, S.; Kontonasiou, E.; Arcipow, A.; Bogdan, A.; Mariottini, F. Indoor air quality, thermal comfort and daylight-Analysis of residential building regulations in eight EU member states. Build. Perform. Inst. Eur. 2015, 100, 1-6.

16. Zukowska, D.; Rojas, G.; Burman, E.; Guyot, G.; Bocanegra-Yanez, M.d.C.; Laverge, J.; Cao, G.; Kolarik, J. Ventilation in low energy residences-A survey on code requirements, implementation barriers and operational challenges from seven European countries. Int. J. Vent. 2020, 1-20. [CrossRef]

17. Guyot, G.; Walker, I.S.; Sherman, M.H. Performance based approaches in standards and regulations for smart ventilation in residential buildings: A summary review. Int. J. Vent. 2019, 18, 96-112. [CrossRef]

18. Guyot, G.; Sherman, M.H.; Walker, I.S. Smart ventilation energy and indoor air quality performance in residential buildings: A review. Energy Build. 2018, 165, 416-430. [CrossRef]

19. Mansson, L.G.; Svennberg, L.A.; Liddament, M.W. Technical Synthesis Report. A Summary of IEA Annex 18. Demand Controlled Ventilating Systems. 1997. Available online: http:/ /www.ecbcs.org/annexes/annex18.htm (accessed on 8 July 2016).

20. Apte, M. A Review of Demand Control Ventilation. 2006. Available online: https://indoor.lbl.gov/sites/all/files/lbnl-60170.pdf (accessed on 25 August 2020).

21. Maripuu, M.-L. Demand controlled ventilation (DCV) for better IAQ and Energy Efficiency. Rehva J. 2011, 48, 26-30.

22. Chenari, B.; Dias Carrilho, J.; Da Gameiro Silva, M. Towards sustainable, energy-efficient and healthy ventilation strategies in buildings: A review. Renew. Sustain. Energy Rev. 2016, 59, 1426-1447. [CrossRef]

23. Moran, F.; Blight, T.; Natarajan, S.; Shea, A. The use of passive house planning package to reduce energy use and $\mathrm{CO}_{2}$ emissions in historic dwellings. Energy Build. 2014, 75, 216-227. [CrossRef]

24. Martinez-Molina, A.; Alamaniotis, M. Enhancing historic building performance with the use of fuzzy inference system to control the electric cooling system. Sustainability 2020, 12, 5848. [CrossRef]

25. IEA-SHC Task 59. Deep Renovation of Historic Buildings Towards Lowest Possible Energy Demand and CO 2 Emission (NZEB). Available online: http:/ / task59.iea-shc.org/ (accessed on 25 August 2020).

26. ATLAS Interreg Alpine Space Project. Advanced Tools for Low-Carbon, High Value Development of Historic Architecture in the Alpine Space. Available online: https:/ / www.alpine-space.eu/projects/atlas/en/home (accessed on 25 August 2020).

27. Conservation of Cultural Heritage—Guidelines for Improving the Energy Performance of Historic Buildings; EN 16883; SIS, Swedish Standards Institute: Stockholm, Sweden, 2017.

28. Exner, D.; Larcher, M.; Belleri, A.; Troi, A.; Haas, F. The "Waaghaus" of Bolzano Energy efficiency, hygrothermal risk and ventilation strategy evaluation for a heritage building. In Proceedings of the 3rd International Conference on Energy Efficiency in Historic Buildings (EEHB2018), Visby, Sweden, 26-27 September 2018; pp. 135-144.

29. Thermal Bridges in Building Construction-Heat Flows and Surface Temperatures—Detailed Calculations; EN ISO 10211:2017; Austrian Standards International: Wiena, Austria, 2018.

30. Lorenzetti, D.M.; Dols, W.S.; Persily, A.K.; Sohn, M.D. A stiff, variable time step transport solver for CONTAM. Build. Environ. 2013, 67, 260-264. [CrossRef]

31. Walton, G.N.E.S. CONTAM93: A multizone airflow and contaminant dispersal model with a graphic user interface. Air Infiltration 1994, 16, 6-8.

32. Brambilla, A.; Sangiorgio, A. Mould growth in energy efficient buildings: Causes, health implications and strategies to mitigate the risk. Renew. Sustain. Energy Rev. 2020, 132, 110093. [CrossRef]

33. Rieser, A. Thermische Sanierungskonzepte für Landwirtschaftliche Holzgebäude unter Beibehaltung der Historischen Baukultur. Master's Thesis, University of Innsbruck, Innsbruck, Austria, 2020.

34. Troi, A.; Bastian, Z. (Eds.) Energy Efficiency Solutions for Historic Buildings. A Handbook; Birkhauser: Basel, Switzerland, 2014; ISBN 9783038216469.

35. Stephen, R.K. Airtightness in UK Dwellings. BRE's Test Results and Their Significance; CRC: London, UK, 1998 ; ISBN 9781860812613.

36. Halliday, S. Technical Paper 6: Indoor Air Quality and Energy Efficiency in Traditional Buildings. Hist. Scotl. Edinb. 2009. Available online: https: / www.historicenvironment.scot/archives-and-research/publications / publication/?publicationId=e0 79f85f-4aa6-4218-b3c9-a59400e211fc (accessed on 25 August 2020).

37. Hubbard, D. Ventilation, infiltration and air permeability ventilation, infiltration and air permeability. J. Archit. Conserv. 2011, 17, 59-73. [CrossRef] 
38. Johnston, D.; Miles-Shenton, D.; Bell, M.; Wingfield, J. Airtightness of Buildings—Towards Higher Performance; Department for Communities and Local Government: Leeds, UK, 2011.

39. Seppänen, O.A.; Fisk, W.J.; Mendell, M.J. Association of ventilation rates and $\mathrm{CO}_{2}$ concentrations with health and other responses in commercial and institutional buildings. Indoor Air 1999, 9, 226-252. [CrossRef]

40. Sundell, J.; Levin, H.; Nazaroff, W.W.; Cain, W.S.; Fisk, W.J.; Grimsrud, D.T.; Gyntelberg, F.; Li, Y.; Persily, A.K.; Pickering, A.C.; et al. Ventilation rates and health: Multidisciplinary review of the scientific literature. Indoor Air 2011, 21, 191-204. [CrossRef]

41. Wargocki, P. The Effects of Ventilation in Homes on Health; INSR: Paris, France, 2012.

42. Eskola, L.; Alex, Ü.; Arumägi, E.; Jokisalo, J.; Donarelli, A.; Siren, K.; Kalamess, T. Airtightness, air exchange and energy performance in historic residential buildings with different structures. Int. J. Vent. 2015, 14, 11-26. [CrossRef]

43. May, N.; Rye, C. Responsible Retrofit of Traditional Buildings. A Report on Existing Research and Guidance with Recommendations; STBA: London, UK, 2012.

44. Changeworks. Energy Heritage-A Guide to Improving Energy Efficiency in Traditional and Historic Homes; Changeworks: Edinburgh, UK, 2008.

45. Humphreys, M.; Nicol, F.; Roaf, S. Technical paper 14: Keeping warm in a cooler house. Hist. Scotl. Edinb. 2011, 14, 1-23.

46. Herrera-Avellanosa, D. Energy Efficiency Improvements in Traditional Buildings: Exploring the Role of User Behaviour in the Hygrothermal Performance of Solid Walls. Ph.D. Thesis, Robert Gordon University, Aberdeen, UK, 2016.

47. Lourenço, P.B.; Luso, E.; Almeida, M.G. Defects and moisture problems in buildings from historical city centres: A case study in Portugal. Build. Environ. 2006, 41, 223-234. [CrossRef]

48. Herrera-Avellanosa, D.; Bennadji, A. Analysis of indoor climate and occupants' behaviour in traditional Scottish dwellings. Energy Procedia 2015, 78, 639-644. [CrossRef]

49. Kalamees, T.; Väli, A.; Kallavus, U.; Kurik, L.; Alev, Ü. Simulated influence of indoor climate and ventilation on schoolwork performance in Estonian manor schools. Int. J. Vent. 2015, 14, 153-164. [CrossRef]

50. Neuhaus, E.; Schellen, H.L. Humidistat-Controlled Heating and Ventilation Systems to Create Preservation Conditions in Historic Buildings in the Dutch Climate; Clima World Congress Wellbeing: Helsinki, Finland, 2007.

51. Rohdin, P.; Dalewski, M.; Moshfegh, B. Indoor environment and energy use in historic buildings-Comparing survey results with measurements and simulations. Int. J. Vent. 2012, 10, 371-382. [CrossRef]

52. Martínez-Molina, A.; Tort-Ausina, I.; Cho, S.; Vivancos, J.-L. Energy efficiency and thermal comfort in historic buildings: A review. Renew. Sustain. Energy Rev. 2016, 61, 70-85. [CrossRef]

53. Nicol, F.; Humphreys, M.A.; Roaf, S. Adaptive Thermal Comfort. Principles and Practice; Routledge: London, UK; New York, NY, USA, 2012; ISBN 9781136336478.

54. Pfluger, R.; Feist, W.; Tietjen, A.; Neher, A. Physiological impairments of individuals at low indoor air humidity. Gefahrst. Reinhalt. Luft 2013, 73, 107-108.

55. Bataille, E. Impact of low energy buildings on indoor air quality (IAQ). Rehva J. 2011, 48, 5-8.

56. Caro, R.; Sendra, J.J. Are the dwellings of historic Mediterranean cities cold in winter? A field assessment on their indoor environment and energy performance. Energy Build. 2021, 230, 110567. [CrossRef]

57. Curtis, R. Climate change and traditional buildings: The approach taken by historic Scotland. J. Archit. Conserv. 2010, 16, 7-27. [CrossRef]

58. Hillier, J.F. Modern Building Services for Listed Historic Buildings: Problems \& Risks. Ph.D. Thesis, Oxford Brookes University, Oxford, UK, 2004.

59. Urquhart, D. Conversion of traditional buildings. Application of the Scottish building standards. Hist. Scotl. Edinb. 2007, 6463.

60. Papaglastra, M.; Leivada, I.; Sfakianaki, K.; Rémi Carrié, F.; Santamouris, M. International comparison of envelope airtightness measurements. In Proceedings of the 3rd European Blower Door Symposium, Kassel, Germany, 30-31 May 2008; pp. 30-31.

61. Kalamees, T.; Kurnitski, J. Moisture convection performance of external walls and roofs. J. Build. Phys. 2009, 33, 225-247. [CrossRef]

62. Alev, Ü. Renovation and Energy Performance Imporvement of Estonian Wooden Rural Houses. Ph.D. Thesis, Tallinn University of Technology, Tallinn, Estonia, 2017.

63. CEN. Thermal Performance of Buildings—Determination of Air Permeability of Buildings_Fan Pressurization Method; EN 13829:2000; CEN: Brussels, Belgium, 2000.

64. DIN Deutsches Institut für Normung. Wärmeschutz und Energie-Einsparung in Gebäuden-Teil 7: Luftdichtheit von GebäudenAnforderungen, Planungs- und Ausführungsempfehlungen Sowie -Beispiele; DIN 4108-7:2011-01; DIN Deutsches Institut für Normung: Berlin, Germany, 2011.

65. Penna, P.; Stuffer, O.; Troi, A.; Cari, V. Villa Castelli-Transformation of historical building into nearly zero energy building. Trans. Tech. Publ. 2019, 887, 148-155.

66. HiBERTool (Historic Buildings Energy Retrofit Tool). Available online: https://www.hiberatlas.com (accessed on 25 August 2020).

67. Cardinale, N.; Rospi, G.; Stefanizzi, P. Energy and microclimatic performance of Mediterranean vernacular buildings: The Sassi district of Matera and the Trulli district of Alberobello. Build. Environ. 2013, 59, 590-598. [CrossRef]

68. Vella, R.C.; Martinez, F.J.R.; Yousif, C.; Gatt, D. A study of thermal comfort in naturally ventilated churches in a Mediterranean climate. Energy Build. 2020, 213, 109843. [CrossRef] 
69. Caro, R.; Sendra, J.J. Evaluation of indoor environment and energy performance of dwellings in heritage buildings. The case of hot summers in historic cities in Mediterranean Europe. Sustain. Cities Soc. 2020, 52, 101798. [CrossRef]

70. Tablada, A.; de Troyer, F.; Blocken, B.; Carmeliet, J.; Verschure, H. On natural ventilation and thermal comfort in compact urban environments-The Old Havana case. Build. Environ. 2009, 44, 1943-1958. [CrossRef]

71. Ionescu, C.; Baracu, T.; Vlad, G.-E.; Necula, H.; Badea, A. The historical evolution of the energy efficient buildings. Renew. Sustain. Energy Rev. 2015, 49, 243-253. [CrossRef]

72. Ding, G.; Ying, X. Embodied and operating energy assessment of existing buildings—Demolish or rebuild. Energy 2019, $182,623-631$. [CrossRef]

73. Sibille, E. Optimized Integration of Ventilation with Heat Recovery in Residential Buildings Through Mentation of Innovative Air Distribution Strategies and Pre-Fabricated Components. Ph.D. Thesis, University of Innsbruck, Innsbruck, Austria, 2015.

74. Pfluger, R.; Längle, K.; Rojas, G. (Eds.) Minimal invasive ventilation systems with heat recovery for school buildings. In Proceedings of the 36th AIVC Conference Effective Ventilation in High Performance Buildings, Madrid, Spain, 23-24 September 2015.

75. Sprecher, F.; Estévez, M. Produktewettbewerb Aktive Überströmer. Bericht des Preisgerichtes; Fachstelle Energie- und Gebäudetechnik, Vewrein Minergie: Zurich, Switzerland, 2011.

76. Pfluger, R.; Rothbacher, M. Active Overflow Ventilation for Refurbishing of School Buildings; Internationale Passivhaustagung: Frankfurt/Main, Germany, 2013.

77. Asdrubali, F.; Baldinelli, G.; Bianchi, F.; Cornicchia, M. Experimental performance analyses of a heat recovery system for mechanical ventilation in buildings. Energy Procedia 2015, 82, 465-471. [CrossRef]

78. Kamendere, E.; Zogla, G.; Kamenders, A.; Ikaunieks, J.; Rochas, C. Analysis of mechanical ventilation system with heat recovery in renovated apartment buildings. Energy Procedia 2015, 72, 27-33. [CrossRef]

79. Abdul Hamid, A.; Johansson, D.; Bagge, H. Ventilation measures for heritage office buildings in temperate climate for improvement of energy performance and IEQ. Energy Build. 2020, 211, 109822. [CrossRef]

80. O'Connor, D.; Calautit, J.K.S.; Hughes, B.R. A review of heat recovery technology for passive ventilation applications. Renew. Sustain. Energy Rev. 2016, 54, 1481-1493. [CrossRef]

81. HiBERatlas (Historic Buildings Energy Regrofit-Atlas). Available online: https:/ / www.hiberatlas.com (accessed on 25 August 2020). 